\title{
Prospective Study of Changes in Anti-HCV Immunoglobulin G Antibody Titers after Treatment with Direct Acting Antiviral Agents
}

Diaa Mohammad Eltebi, Islam Abdel-Mawla Ammar, Mohammad Abu Elsoud Mohammad

* Department of Tropical Medicine, Faculty of Medicine, Al-Azhar University, Cairo.

Corresponding author: Mohammad Abu Elsoud Mohammad, email: Muhammadaboelsoud@gmail.com

\begin{abstract}
Introduction: worldwide, approximately 180 million people are living with $\mathrm{CHC}$, which corresponds to a global prevalence of $1.1 \%$ and millions more are newly infected each year. Annually, 700.000 people die from HCV-related complications, including cirrhosis and hepatocellular carcinoma (HCC). Aim of the work: the present study investigated the dynamics of change in various HCV antibodies in patients with CHC who achieved SVR after DAAs. Methodology: this was a prospective case-control study that was conducted on 150 patients. They were categorized into three main groups:

Group I: included 100 patients with chronic HCV infection as diagnosed by SRT-PCR. They were submitted to treatment with DAAs for 12 weeks.

Group II (positive control group): Included 25 patients who presented with $\mathrm{CHC}$ infection as diagnosed by positive anti-HCV IgG antibodies and positive HCV SRT-PCR, but either refuse or postpone $\mathrm{HCV}$ therapy or the treatment of $\mathrm{HCV}$ itself was contraindicated.

Group III (negative control group): included 25 patients, apparently healthy individuals who test positive for anti-HCV IgG antibodies, but negative HCV SRT-PCR.

$\mathrm{HCV}$ IgG Ab titers was assessed by commercially available third-generation enzyme-linked immunosorbent assay (ELISA) at base line, end of treatment and then at the $24^{\text {th }}$ week (i.e. 12 weeks after the end of treatment). Results: as regard HCVAb, it showed a significant statistical difference (pvalue $<0.001$ ) between titer results at baselin $12^{\text {th }}$ week and $24^{\text {th }}$ week in patients group I; as HCV Ab titers were $3.3 \pm 0.2 \mathrm{mg} / \mathrm{dl}$ at baseline and declined to $2.7 \pm 0.2$ at $12^{\text {th }}$ week and $2.4 \pm 0.3$ at $24^{\text {th }}$ week. But, there was no statistical significant difference (p-value $>\mathbf{0 . 0 5}$ ) between HCV Ab titer results at baseline, $12^{\text {th }}$ week and $24^{\text {th }}$ week in the studied positive control patients group II as HCV Ab titers were $3.1 \pm 0.2$ at baseline, $3.2 \pm 0.2$ at 12 th week and $(3.2 \pm 0.1)$ at $24^{\text {th }}$ week week. Also, there was no statistical significant difference (p-value $>\mathbf{0 . 0 5}$ ) between HCV Ab titer results at baseline, $12^{\text {th }}$ week and $24^{\text {th }}$ week in studied negative control patients group III as HCV Ab titers were $1.22 \pm 08$ at baseline, $(1.23 \pm 0.08)$ at $12^{\text {th }}$ week and $1.24 \pm 0.07$ at $24^{\text {th }}$ week.
\end{abstract}

Conclusion: HCV antibody titer appeared to continue to decrease after eradication of HCV by DAAs therapy.

Keywords: CHC: chronic hepatitis c virus, DAAs ( Direct acting antiviral agents), HCC (Hepatocellular carcinoma), HCV (Hepatitis C virus), SVR (sustained virological response), SRT PCR (Serum real time polymerase chain reaction ).

\section{Introduction}

$(\mathrm{HCV})$ is a major cause of liver related morbidity and mortality worldwide and represents a major public health problem ${ }^{(\mathbf{1})}$. Worldwide, approximately 180 million people are living with chronic HCV, which corresponds to a global prevalence of $1.1 \%$, and millions more are newly infected each year. Annually, 700000 people die from HCVrelated complications, including cirrhosis and $\mathrm{HCC}^{(2)}$.

Egypt has the highest prevalence of $\mathrm{HCV}$ in the world (Predominantly genotype 4), which has been attributed to previous public health eradication schemes for schistosomiasis. The

prevalence was as high as $22 \%{ }^{(3)}$. Even higher $\mathrm{HCV}$ infection rates, up to $60 \%$, have been reported in older individuals, in rural areas such as the Nile Delta and in lower social classes. The prevalence of antibodies to HCV in Egypt was 10-fold greater than in the United States and Europe ${ }^{(4)}$. The purpose of diagnosis of viral infection is to allow the infected persons to be identified and treated. Thus, diagnosis of viral infection is important to prevent disease progression and viral spread. Majority of primary $\mathrm{HCV}$-infected patients are asymptomatic; thus symptoms could not be used as specific indicators for HCV infection. $\mathrm{HCV}$ viremia could still exist despite a normal 
serum alanine aminotransferase (ALT) level. Therefore, virological methods rather than ALT levels are used to diagnose $\mathrm{HCV}$ infection ${ }^{(5)}$.In general, the virological methods for examining viral infections include indirect and direct tests. The indirect tests are used to detect antibody induced by viral infection, including IgM for recent infection and $\mathrm{IgG}$ for recent or past infection. The direct tests include virus isolation, detection of viral antigens and viral nucleic acids. At present, it is difficult to isolate and culture $\mathrm{HCV}$ using clinical specimens. Furthermore, anti-HCV IgMs could be detected not only in $50 \%-93 \%$ of patients with acute HCV but also in $50 \%-70 \%$ of CHC patients ${ }^{(6)}$. Therefore, anti-HCV IgM cannot be used as a reliable marker for the acute $\mathrm{HCV}$ infection, and IgM assays have not been used in clinical practice $^{(7)}$. At present, diagnostic assays for anti-HCV total antibody, viral core antigen, and viral genomic RNA are used in clinical practice (8).The goal of antiviral treatment for $\mathrm{CHC}$ is to halt disease progression, prevent cirrhosis decompensation and reduce the risk of HCC. However, it is really difficult to design and carry out clinical trials to provide direct evidence related to these outcomes ${ }^{(\boldsymbol{9})}$. At present, SVR is the primary endpoint of successful therapy and is associated with durable clearance of virus . CHC patients with a SVR after antiviral therapy had a lower risk of all-cause mortality than patients with no $\mathrm{SVR}^{(10)}$. Abd Alla and El-Awady ${ }^{(11)}$ published new data regarding the use ofcellular HCVPCR in evaluation of antiviral treatment outcomes.

They reported: a) HCV peripheral blood mono nuclear cells (PBMCs) PCR is a valid diagnostic test that has the major advantage of diagnosing intracellular infection when SRTPCR is negative. b) HCV antisense strands are detected more often in naïve patients and sense stands are detected more often in post-treatment patients. c) The overall expected relapse rate for the used treatment regimens is $18.02 \%$, d) Intracellular infection of PBMCs is associated with post-HCV liver cirrhosis in naïve patients who show positivity for serum anti-HCV IgGantibodies but negative results by SRT-PCR. e) Eradication of intracellular HCV antisense and sense strands is recommended to prohibit sequelae of RNA seroconversion ${ }^{(11)}$.

\section{Patients and Methods}

This was a prospective case-control study and it was conducted on 150 patients. The studied patients visited Beet-Elzakah Outpatient Clinic, Al-Azhar University and they were classified into three groups:

Group I: included 100 patients with chronic HCV infection as diagnosed by SRTPCR. They were submitted to treatment with DAAs for $12^{\text {th }}$ weeks.

Group II (positive control group): included 25 patients who presented with chronic HCV infection as diagnosed by positive anti-HCV IgG antibodies and positive HCV SRT-PCR, but either refused or postponed $\mathrm{HCV}$ therapy or the treatment of $\mathrm{HCV}$ itself was contraindicated.

Group III (negative control group) included 25 apparently healthy individuals who showed positive for anti-HCV IgG antibodies, but negative HCV SRT-PCR. Their serology results were used to calculate the cutoff point of serum anti-HCV IgG antibody reading at each follow-up time. HCV IgG Ab titers assessed by commercially available third-generation (ELISA), at base line, end of treatment and then at the $24^{\text {th }}$ week (i.e. 12 th weeks after the end of treatment). Treatment considered successful when patients became non-viremic as identified by negative HCV RNA serum PCR at 12th weeks from the end of the treatment regimens (SVR).

We excluded patients who were co-infected with or HBV, HCC or other extrahepatic malignancy, total serum bilirubin more than $3 \mathrm{mg} / \mathrm{dl}$, serum albumin less than $2.8 \mathrm{~g} / \mathrm{dl}$, INR more than 1.7 , platelet count less than $50,000 / \mathrm{mm}$, renal impairment with GFR less than $30 \mathrm{ml} \mathrm{/} \mathrm{minute} \mathrm{and} \mathrm{non-compliant}$ patients.

All patients were subjected to: written consent before therapy, complete history taking; which include history of other comorbid conditions such as diabetes mellitus, cardiac disease and renal failure. History of previous treatment with anti$\mathrm{HCV}$ medicines (e.g. peg interferon plus ribavirin, Sofosbuvir plus Ribavirin, or other combination regimens) was also evaluated. Sensitivity to any other drug had to be checked out, full clinical examination; which included manifestations of chronic liver disease (such as jaundice, flapping tremors, lower limb edema, organomegaly, ascites).

Blood samples were collected from all patients and submitted to the following, serum HCV RNA quantitative by $\mathrm{PCR}$ at baseline, $\mathrm{HCV}$ IgG Ab titer 
by third generation ELISA at baseline,Hepatitis B surface antigen (HBsAg), complete blood picture (CBC): hemoglobin concentration ( $\mathrm{Hb} \%)$, red blood cells (RBCs), white blood cells (WBCs), platelet count. Liver profile: alanine aminotransferase (ALT), aspartate aminotransferase (AST), albumin, total bilirubin and direct bilirubin, prothrombin time and INR,renal function tests, serum creatinine , abdominal ultrasonographic examination for the liver (size, surface, echogenicity, focal lesions, and biliary tree), portal and splenic vein diameters and patency, splenic size, ascites and abdominal masses.All patients was submitted to serum $\mathrm{HCV}$ RNA quantification by PCR at the $12^{\text {th }}$ week and $24^{\text {th }}$ week of treatment All patients was submitted to serum HCV IgG antibody screening test by the third generation ELISA $12^{\text {th }}$ week and $24^{\text {th }}$ week of treatment.

\section{Statistical Methods:}

SPSS statistical software package (V. 17.0, Echo soft Corp., USA, 2008) was used for data analysis. Results were expressed as means \pm standard deviation of the means (SD). Differences between groups were analyzed either by using the Chi square test or student's t test and nonparametric (Mann Whitney test) for comparison between two groups or ANOVA test for multiple group comparison. Spearman rank correlation coefficient was used to determine significant correlations among different parameters. The analysis was performed using Statistical Analysis System, version 6.03, on an IBM at personal computer.

\section{Results}

- The average age was $54.7 \pm 7.6$ years in Group I, $54.8 \pm 3.3$ years in group II and 54 \pm 7.5 years in group III, with no statistical significant difference ( $\mathrm{p}$-value > 0.05) between all groups as regard age.

- As regard gender, it was non-significant between the three groups, as they were $71 \%$ of studied patients were males and the other $29 \%$ were females for group I , $64 \%$ of studied patients were males and the other $36 \%$ were females for group II and $60 \%$ of the studied patients were males and the other $40 \%$ were females for group III.

- In the studied group there was no statistical significant difference (pvalue > 0.05) before and after therapy as regard $\mathrm{CBC}$ parameters (Hb , WBCs , platelets), liver function tests parameters ( $\mathrm{T}$. bilirubin, serum albumin, INR), AFP , kidney function test (serum creatinine) .

As regard liver enzyme parameters (ALT and AST) in group I in figure 1.

It showed statistically significant difference between baseline, 12 week and 24 week results.

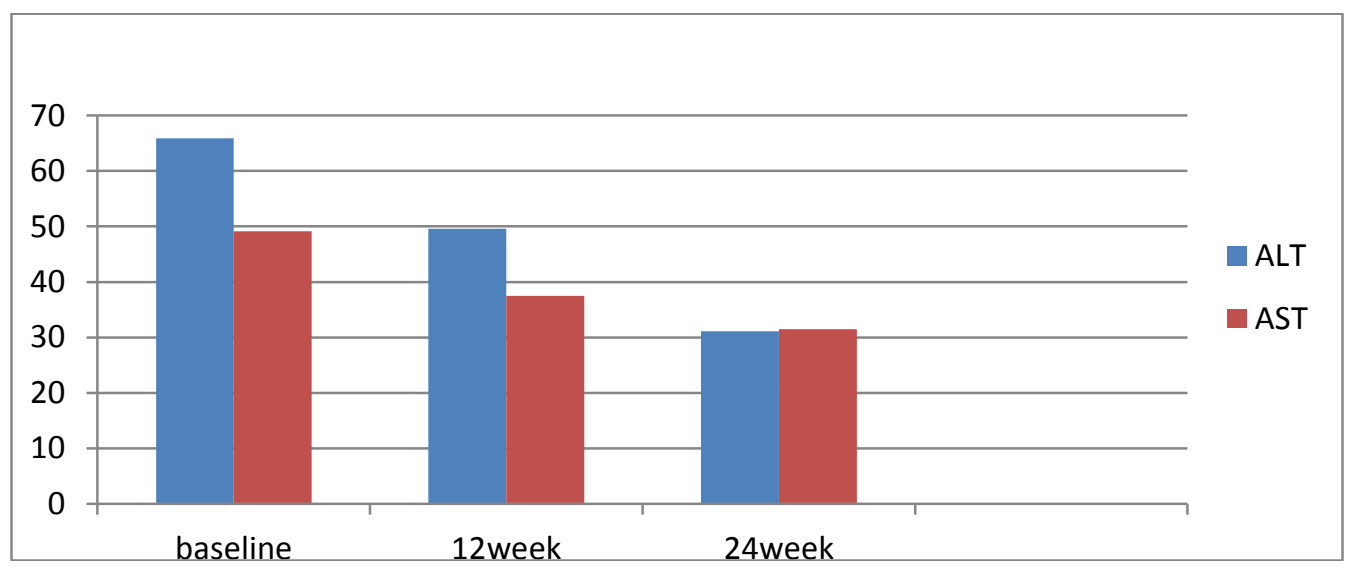

Figure 1: comparison between ALT and AST at baseline, $12^{\text {th }}$ week and $24^{\text {th }}$ week in patients group

Table 1: showed the laboratory data of studied patients.(PCR at baseline, 24 week ) 
As regard HCV RNA PCR, $100 \%$ of studied patients group I were positive at baseline while at $\mathbf{2 4}^{\text {th }}$ week only $3 \%$ were positive and $97 \%$ were negative.

\begin{tabular}{|l|l||l||}
\hline $\begin{array}{l}|l| \mid \\
\text { Laboratory findings } \\
\text { Patients }\end{array}$ & Studied cases $(\mathrm{N}=100)$ \\
\hline \multirow{2}{*}{ HCV RNA PCR } & Baseline & $\begin{array}{l}100 \% \text { Positive }\left(3.5 \pm 6.1 \times 10^{6}\right) \\
97 \% \text { Negative }\end{array} \quad 3 \%$ Positive \\
\hline \hline
\end{tabular}

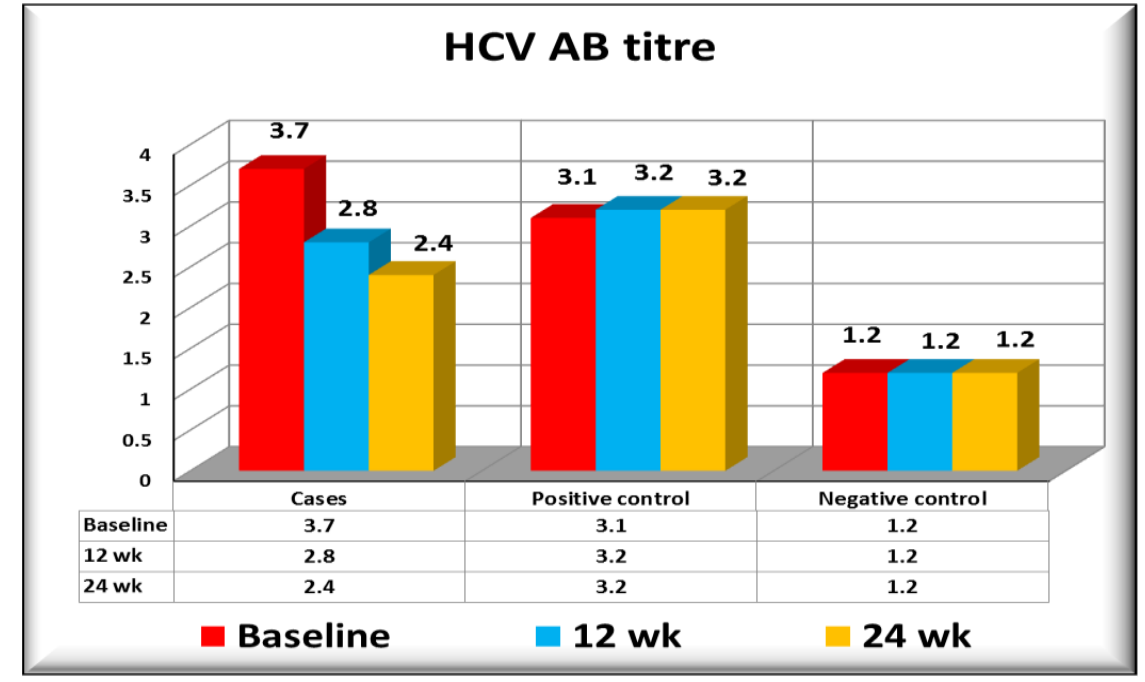

Figure 2: comparison between studied groups (cases, positive control and negative control) as regard HCV Ab titer.

This figure showed a significant decrease of HCV Ab titers at $12 \mathrm{wk}$ and $24 \mathrm{wk}$ of treatment in patient group I by comparison with other non-treated group.

Table 2: post-Hoc test for comparison between studied groups (cases, positive control and negative control) as regard HCV Ab titer.

There was a high significant statistical difference between HCV Ab titer at baseline, 12 week, 24 week between the three groups.

\begin{tabular}{|c|c|c|c|c|}
\hline \multicolumn{2}{|c|}{$\begin{array}{l}\text { Patients } \\
\text { Variables }\end{array}$} & $\begin{array}{l}\text { Cases Vs } \\
\text { Positive con. }\end{array}$ & $\begin{array}{l}\text { Cases Vs } \\
\text { Negative con. }\end{array}$ & $\begin{array}{l}\text { Positive con. Vs } \\
\text { Negative con. }\end{array}$ \\
\hline \multirow{2}{*}{ Baseline } & SD & 0.2 & 2.1 & 1.9 \\
\hline & p-value & $<0.001 *$ & $<0.001 *$ & $<0.001 *$ \\
\hline \multirow{2}{*}{12 week } & SD & 0.4 & 1.6 & 1.9 \\
\hline & p-value & $<0.001 *$ & $<0.001 *$ & $<0.001 *$ \\
\hline \multirow{2}{*}{24 week } & SD & 0.7 & 1.2 & 1.9 \\
\hline & p-value & $<0.001 *$ & $<0.001 *$ & $<0.001 *$ \\
\hline
\end{tabular}

Table 3: diagnostic performance of $\mathrm{HCV}$ Ab titer in discrimination of patient's group and positive control group

Receiver operating characteristics (ROC) curve defined the best cut off value of serum HCV Ab titer which was $<2.7$, with sensitivity of $95 \%$, specificity of $96 \%$.

\section{Discussion}

\begin{tabular}{|c|c|c|}
\hline Cut off & Sensitivity & Specificity \\
\hline \hline$<2.7$ & $95 \%$ & $96 \%$ \\
\hline
\end{tabular}

$\mathrm{HCV}$ infection is a major cause of CLD worldwide, ultimately leading to cirrhosis and HCC. Approximately, 130-150 million people are infected with $\mathrm{HCV}$; each year, besides an estimated 399000 people die from complications of $\mathrm{HCV}$ including fatty liver 
(cirrhosis), malignant neoplastic disease HCC and liver failure. Unluckily, many people with $\mathrm{HCV}$ only know about their infection when they experience symptoms of cirrhosis or liver cancer ${ }^{(2)}$. The goal of antiviral therapy in patients with chronic hepatitis $\mathrm{C}$ virus (HCV) infection is to attain a sustained virological response (SVR), resulting in viral eradication in most patients .[12]

Although viral clearance is well documented in patients with SVR, changes in antibodies to HCV status remain unclear. The diagnosis of resolved hepatitis $\mathrm{C}$ infection is based on the detection of the HCV-specific antibody and the absence of detectable serum HCV-RNA. Complete or partial seroconversion of the HCV antibody is characterized by a progressive non-synchronized loss of these antibodies ${ }^{(\mathbf{1 3})}$.

Patients with SVR are frequently lost to follow-up soon after therapy because these patients are considered cured and less interested to come for a post-treatment check-up. Therefore, regular and long-term follow-up of patients with SVR is not well documented, in particular, the dynamics of changes in the HCV antibody (12). In past, there were some researches which studied the relation between $\mathrm{HCV} \mathrm{Ab}$ titers and viral loads in patients were treated with Peg INF. Our work studies the relation between $\mathrm{HCV}$ Ab titers in patients who were treated with (DAAs). The aim of this study was to investigate the dynamics of change in various $\mathrm{HCV}$ antibodies in patients with $\mathrm{CHC}$ who achieved SVR after antiviral therapy with DAAs.

This study was a prospective study which took place at Al-Azhar University Hospitals. It was designed for evaluation of pretreatment serum anti-HCV IgG antibodies titers in chronic $\mathrm{HCV}$ infection with correlation to baseline serum viral load, identification the effect of DAAs treatment on the anti-HCV IgG antibody titers in 12 and 24 weeks of DAAs treatment, and recognition of individual cases presented with post-treatment stationary or rising anti-HCV IgG antibody titers to correlate with serum HCV-RNA by serum real timepolymerase chain reaction (SRT-PCR).The study included 150 patients infected with chronic HCV they were divided according to the presence or absence of cellular HCV RNA, and they received DAAs treatment or not, into three groups;
- Group I: included 100 patients with Chronic HCV infection as diagnosed by SRTPCR. They will be submitted to treatment with DAAs for 12 weeks,

- Group II: included 25 patients who presented with Chronic $\mathrm{HCV}$ infection as diagnosed by positive anti-HCV IgG antibodies and positive $\mathrm{HCV}$ SRT-PCR, but either refuse or postpone $\mathrm{HCV}$ therapy or the treatment of $\mathrm{HCV}$ itself is contraindicated, and

- Group III: included 25 apparently healthy individuals who test positive for anti-HCV IgG antibodies, but negative HCV SRT-PCR. Their serology results will be used to calculate the cutoff point of serum anti-HCV IgG antibody reading at each follow-up time.

All studied individuals at the beginning of the study were subjected to laboratory tests, that included qualitative serum HCV-RNA by SRT-PCR, HCV IgG Abtiter by ELISA, liver profile (included liver enzymes, serum bilirubin, serum albumin, the international normalized ratio, and alpha feto protein), complete blood picture (CBC), serum creatinine, and fasting blood sugar. Also abdominal ultrasound was performed to all studied individuals. Serum HCV-RNA by SRTPCR, and HCV IgG Abtiter by ELISA were repeated at $12^{\text {th }}$ week of the study (i.e. at the end of treatment of Group I) and at $24^{\text {th }}$ week of the study (i.e. at the end of treatment of group I).

Group I patients (100 patients), received DAAs in the form of sofosbuvir + daclatasvir for 12 weeks, and SVR was defined as a viral load below the lower limit of quantification 12 weeks after the end of treatment.

\section{The following characteristics were found in the studied groups:}

- The average age was $54.7 \pm 7.6$ years in group I, $54.8 \pm 3.3$ years in group II and $54 \pm 7.5$ years in group III, with no statistical significant difference (pvalue $>0.05$ ) between all groups as regard age. 
- The majority of patients were male and represented $71 \%$ in group I, $64 \%$ in Group II and 60\% in group III, with no statistical significant difference (pvalue $>0.05$ ) between all groups as regard gender.

- Liver transaminases: ALT and AST showed improvement in group I patients, from $(65.9 \pm 19.7$ and $49.1 \pm$ $7.2 \mathrm{U} / \mathrm{l}$, respectively) at baseline to $(49.6 \pm 7.1$ and $37.5 \pm 25.8 \mathrm{U} / \mathrm{l}$, respectively) at 12 week and (31.08 \pm 9.2 and $31.5 \pm 13.6 \mathrm{U} / \mathrm{l}$, respectively) at 24week, with statistical significant difference (p-value < $\mathbf{0 . 0 5}$ ), (The upper normal level was 45, $40 \mathrm{U} / 1$, respectively). But, there was no statistical significant difference (pvalue > 0.05) as regard ALT and AST, at $0,12^{\text {th }}$ week and $24^{\text {th }}$ week of the study, neither in group II, nor group III. This improvement of liver transaminases in group I, can be explained by the cessation of inflammatory process after viral clearance with DAAs treatment and these results were in agreement with results of Mohamed et al. ${ }^{(14)}$ who reported statistically significant improvement in liver transaminases ALT and AST from 63.2 \pm 27.6 and $58.1 \pm 19.1 \mathrm{U} / \mathrm{l}$, respectively at baseline to $27.6 \pm 18.3$ and $31.4 \pm$ 23.4, respectively after treatment .[14]It also in agreement with results of Nathanael (15) who studied the impact of directly acting antivirals on the enzymatic liver function of liver transplant recipients with recurrent hepatitis $\mathrm{C}$ in 21 patients with elevated liver enzymes or advanced fibrosis/ compensated cirrhosis caused by recurrent $\mathrm{HCV}$ were treated with sofosbuvir either in combination with simeprevir, or in combination with ribavirin or daclatasvir with or without ribavirin for 12 weeks and they found a significant statistical difference between ALT and AST before and after treatment from $97 \pm$ 80 and $105 \pm 76 \mathrm{U} / \mathrm{l}$, at baseline to 18 \pm 8 and $26 \pm 9$, respectively ${ }^{(15)}$.

As regard other laboratory parameters : they included liver parameters (ALB, BIL, and INR), serum creatinine and $\mathrm{CBC}$; there was no statistical significant difference (pvalue > 0.05) between the studied groups, at baseline, $12^{\text {th }}$ week and $24^{\text {th }}$ week of the study.

- As regard HCV RNA PCR: 100 patients (100\%), of group I patients were positive at baseline, while at 24 week only three patients (3\%) showed failure of treatment and 97 patients (97\%), showed Sustained Virological Response (SVR), with highly statistical significant difference (pvalue $<0.001$ ). during. But, there was no statistical significant difference (pvalue > 0.05) as regard HCV RNA, at $0,12^{\text {th }}$ week, and $24^{\text {th }}$ week of the study, neither in Group II, nor Group III. This finding is in agreement with results of EL-Nahaas et al., (16) who studied high SVR using generic DAAs in the treatment of CHC Egyptian patients. It was an observational study that included 234 chronic $\mathrm{HCV}$ classified into two groups, group A (101 patients ) received sofosbuvir $400 \mathrm{mg}$ plus Daclatasvir $60 \mathrm{mg}$ and group B (134 patients) received generic Sofosbuvir $400 \mathrm{mg}$ plus Daclatasvir $60 \mathrm{mg}$ with or without ribavirin for 12 weeks. The end point was SVR 12 weeks after treatment. The results were $100 \%$ SVR for group A and $99 \%$ for group B.

- It is also in agreement with results of Calleja ${ }^{(17)}$ who studied effectiveness, safety and clinical outcomes of direct acting antiviral therapy in $\mathrm{HCV}$ genotype 1 infection in 1758 patients in 35 centers across spain between April 2015 and Febraury 2016 treated by two regimens and SVR was $96.8 \%$ with OMV/PTVr/dsv + RBV and 95.8 $\%$ with $\mathrm{LDV} / \mathrm{SOF}+\mathrm{RBV}$

- $\quad$ As regard HCV IgG Abs titer; there was a highly statistical significant difference (p-value $<\mathbf{0 . 0 0 1}$ ) between $\mathrm{HCV}$ Abs titre at baseline, 12 week and 24 week in group I patients, as $\mathrm{HCV} \mathrm{Ab} \mathrm{titers} \mathrm{were}(3.3 \pm 0.2)$ at baseline to $(2.7 \pm 0.2$,) at 12 week and $(2.4 \pm 0.3)$ at 24 week. While, there was no statistical significant difference (p- 
value > $\mathbf{0 . 0 5}$ ), as regard $\mathrm{HCV}$ Abs titre at baseline, 12 week and 24 week, neither in group II as HCV Abtiters were $(3.1 \pm 0.2)$ at baseline to (3.2 $\pm 0.2)$ at 12 week and $(3.2 \pm 0.1)$ at 24week, nor in group III as HCV Ab titers were $(1.22 \pm 08)$ at baseline to $(1.23 \pm 0.08)$ at 12 week and $(1.24 \pm$ 0.07 ) at 24 week.

- Our results are in agreement with those of Sara et al. ${ }^{(12)}$ who found that there was a marked decrease in the $\mathrm{HCV}$ antibodies directed against the nonstructural proteins during a follow-up study, of patients with SVR to IFN-a-2b based therapy, with statistically significant change between mean $\mathrm{HCV}$ antibody before therapy and in the last available serum sample $(\mathrm{P}<0.001)$. Also he found that; the follow up of the control patients showed no statistically significant change between mean $\mathrm{HCV}$ Abs in the first and the last measurements, and $\mathrm{HCV}$ antibody titres for structural and non-structural proteins remained unchanged.

- Our results are in agreement with results of Hidenori et al. (18) who found that $\mathrm{HCV}$ antibody titer appeared to continue to decrease during the 10 years after eradication of HCV by IFN therapy.

- Also our results are in agreement with those of Saba et $\boldsymbol{a l} .{ }^{(19)}$ who reported that $\mathrm{HCV}$ Ab titers were higher non responders to DAAs, than responders, with statistical significant difference.

- We found that the diagnostic performance of $\mathrm{HCV} \mathrm{Ab}$ titer in discrimination between group I, and group II, was less than 2.7 with sensitivity $95 \%$ and Specificity $96 \%$.

- In this study, there was no statistical significant (p-value > 0.05) correlation between the decline of HCV Abs titers at $12^{\text {th }}$ week, and $24^{\text {th }}$ week of treatment, and other studied parameters in group $\mathbf{I}$.

\section{Conclusion}

In conclusion, HCV antibody titers decreased after eradication of HCV by DAAs therapy. Because a decrease in HCV antibody represented, in part, the changes in immune status associated with $\mathrm{HCV}$ infection, this decrease in $\mathrm{HCV}$ antibody titer may be associated with changes caused by diseases related to $\mathrm{HCV}$ infection.

\section{References:}

1. Alberti A and Benvegnu L (2003): Management of hepatitis C. Hepatology, 38:104-118.

2. Li HC and Lo SY (2015): HCV virus, Virology, diagnosis and treatment World J Hepatol., 7(10): 1377-1389.

3. Holmberg SB, Kozarsky PE and Magill AJ (2012): CDC Health Information for International Travel, New York: Oxford University Press.

4. Frank C, Mohamed MK and Strickland GT (2000): The role of parenteral antischistosomal therapy in the spread of hepatitis $C$ virus in Egypt. Lancet, 355: 887-891.

5. Chevaliez $S$ and Pawlotsky JM (2009): How to use virological tools for optimal management of chronic hepatitis C. Liver Int., 29 (1): 9-14.

6. Sagnelli E, Coppola $\mathbf{N}$ and Marrocco C (2003): Diagnosis of $\mathrm{HCV}$ related acute hepatitis by serial determination of IgM to $\mathrm{HCV}$ : a preliminary observation. J Biol Regul Homeost Agents, 17: 207210.

7. Yuki N, Hayashi N and Ohkawa K (1995): The significance of immunoglobulin $\mathrm{M}$ antibody response to hepatitis $\mathrm{C}$ virus core protein in patients with chronic hepatitis C. Hepatology, 22:402-406.

8. Albertoni $G$ and Castelo $G$ (2003): Mini review: current molecular methods for the detection and quantification of hepatitis $\mathrm{B}$ virus, hepatitis $\mathrm{C}$ virus, and human immunodeficiency virus type 1. Int J Infect Disease, 25:145-149.

9. Toshikuni $N$ and Arisawa T (2014): Hepatitis C-related liver cirrhosis strategies for the prevention of hepatic decompensation, hepatocarcinogenesis, and mortality. World J Gastroenteroly, 20: 2876-2887.

10. Backus LI and Boothroyd DB (2011): A sustained virologic response reduces risk of all-cause mortality in patients with hepatitis C. Clin Gastroenterol Hepatol., 9:509-516. 
11. Abd Alla A and El Awady MK (2017): Hepatitis C virus RNA strands detection in peripheral blood mononuclear cells legitimizes virus eradication in negative serum PCR naïve and post-treatment patients. J Clin Transl Hepatol., 5:1-8.

12. Sarah $M$ and Michelle $M$ (2008): Sustained virological response associated with clearance of hepatitis $\mathrm{C}$ virus RNA and a decrease in hepatitis $C$ virus antibody. Liver International., 29(4): 511-517.

13. Takaki A and Wiese $M$ (2000): Cellular immune responses persist and humoral responses decrease two decades after recovery from a singlesource outbreak of hepatitis C. Nat Med., 6:578-82.

14. Mohamed MS and Hanafy AS (2017): Sofosbuvir and Daclatasvir plus Ribavirin Treatment Improve Liver Function Parameters and Clinical Outcomes in Egyptian Chronic Hepatitis C Patients Eur J Gastroenterol Hepatol., 1368-1372.
15. Nathanael R, Eckart $S$ and Anja (2016): The impact of directly acting antivirals on the enzymatic liver function of liver transplant recipients with recurrent hepatitis C2016 Transpl Infect Dis., 18: 896-903.

16. El-Nahaas $S$ and Rabab F (2018): High sustained virologic response using generic directly acting antivirals in the treatment of chronic hepatitis $\mathrm{C}$ virus Egyptian patients. Eur J Gastroenterol Hepatol., (10):1194-1199.

17. Calleja JL and Crespo J (2017): Effectiveness, safety and clinical outcomes of direct acting antiviral therapy in $\mathrm{HCV}$ genotype1 infection. Journal of hepatol., (19):1165-1169.

18. Hidenori $T$ and Takashi $K$ (2005): Changes in Hepatitis C Virus (HCV) Antibody Status in Patients with Chronic Hepatitis C after Eradication of HCV Infection by Interferon Therapy. Clin Infect Dis., 40(6):e49-54.

19. Saba A and Sayed A (2018) : Role of anti-hepatitis $\mathrm{C}$ virus (HCV)signal to cut off ratio in following up patients received anti HCV therapy in Egypt The Egyptian Journal of Hospital medicine, 72(2) 4034-4038. 